\title{
KERAGAAN TEKNOLOGI GARAM PADA BEBERAPA KAWASAN SENTRA PRODUKSI DI KABUPATEN LAMONGAN
}

\author{
"Budi Wardono dan Istiana \\ Balai Besar Penelitian Sosial Ekonomi Kelautan dan Perikanan \\ Gedung Balitbang KP I Lt. 4 \\ Jalan Pasir Putih Nomor 1 Ancol Timur, Jakarta Utara \\ Telp: (021) 64711583 Fax: 64700924 \\ *e-mail: budi_ward@yahoo.com \\ Diterima 3 Januari 2014- Disetujui 25 Mei 2014
}

\begin{abstract}
ABSTRAK
Kabupten Lamongan mempunyai potensi tambak garam yang tergolong luas (350 ha). Untuk mencapai hasil produksi garam yang optimal, pemerintah telah mengimplementasikan berbagai program, seperti: PNPM Mandiri KP (Pemberdayaan Usaha Garam Rakyat/PUGAR), Iptekmas Garam, Teknologi Tepat Guna (TTG) garam Arifin Sedayu Lawas yang tumbuh dimasyarakat. Dalam pelaksanaannya, dalam program PUGAR dilakukan bantuan pengembangan usaha dan perberdayaan masyarakat dalam menumbuh kembangkan usaha garam rakyat sesuai dengan potensi, dan diharapkan mampu meningkatkan produktifitas dan nilai tambah usaha garam. Penelitian mengenai keragaan teknologi garam pada beberapa kawasan sentra produksi di Kabupaten Lamongan telah dilakukan pada tahun 2013. Tujuan penelitian ini adalah untuk mengetahui keragaan teknologi garam yang ada dimasyarakat dan peluang pengembangannya. Data yang digunakan merupakan data primer yang diperoleh dari hasil obeservasi dan wawancara di lapang. Data dianalisis dengan pendekatan deskriptif-kualitatif. Hasil penelitian menunjukkan bahwa peningkatan produktifitas dapat dilakukan melalui program PUGAR, terutama dengan adanya bantuan paket yang disertai pendampingan oleh PPTK, dan upaya peningkatan produktifitas garam dihasilkan dari TTG Garam Arifin Sedayu Lawas serta upaya peningkatan kualitas garam rakyat dilakukan melalui proses pencucian yang dihasilkan dari rekayasa teknologi sederhana hasil P3SDLP yang mampu menghasilkan garam dengan kualitas garam konsumsi. Untuk mendukung peningkatan produktifitas tambak garam di Kabupaten Lamongan, perlu dilakukan peningkatan kapasitas kelembagaan khususnya melalui pembentukan kelembagaan koperasi sebagai wadah usaha yang menaungi kepentingan anggota kelompok terutama dalam hal menjaga stabiltas harga produksi garam.
\end{abstract}

Kata kunci: inovasi, Teknologi Tepat Guna (TTG), nilai tambah, produktifitas, pugar

\section{Abstract : Salt Technology Performanceon Several Production Centers in Lamongan Regency. by: Budi Wardono and Intiana}

Lamongan district has a potential of 350 ha of salt ponds, to achieve optimal results carried out through various programs such as PNPM Mandiri KP, Iptekmas, Appropriate Technology which grows in the community. Program for Empowerment of Salt hereinafter referred PUGAR through business development assistance and community empowerment in efforts to according the potential of rural people is expected to increase the productivity and value-added salt business. The purpose of a study to determine the variability of existing salt technology and development opportunities in the community. The results obtained show that the increase in productivity can be made through the program with the help of the package PUGAR along with mentoring by PPTK, efforts to increase the productivity of salt produced from TTG Sedayu Lawas potentially improve the productivity of the land of salt. Efforts to improve the quality of salt through leaching process from a simple technologies that are capable of producing results $P 3 S D L P$ with quality salt consumption. Institutional capacity building is done through the establishment of cooperative institutions as a container that houses the business interests of members of the group, especially in terms of being stability price of salt production.

Keywords : innovation, appropriate technology, valueadded, productivity, pugar

\section{PENDAHULUAN}

Usaha pemerintah untuk mencapai swasembada garam tahun 2014 diimplementasikan melalui beberapa upaya. Upaya tersebut dilakukan melalui program PUGAR (Pemberdayaan Usaha Garam Rakyat) terutama dengan memberikan fasilitasi bantuan pengembangan usaha bagi petambak garam rakyat dan masyarakat pesisir dalam wadah Kelompok Usaha Kelautan dan
Perikanan (KUKP). KUKP merupakan kelembagaan masyarakat kelautan dan perikanan pelaksana PNPM Mandiri KP untuk penyaluran bantuan pengembangan usaha bagi anggota kelompok.

Untuk mencapai hasil yang optimal pelaksanaan PNPM Mandiri KP, maka KUKP didampingi oleh tenaga pendamping, Penyuluh Perikanan PNS, Penyuluh Perikanan Tenaga Kontrak (PPTK), penyuluh swadaya dan/atau tenaga pendamping PUGAR. Melalui 
pelaksanaan PNPM Mandiri KP diharapkan KUKP dapat menjadi kelembagaan ekonomi yang dimiliki dan dikelola petambak garam rakyat, dan masyarakat pesisir lainnya. Melalui PUGAR bantuan pengembangan usaha dan perberdayaan masyarakat dalam menumbuhkembangkan usaha garam rakyat sesuai dengan potensi desa.

Garam merupakan salah satu potensi Kecamatan Brondong dengan luas lahan sekitar $350 \mathrm{Ha}$. Selamatiga tahun terakhir, jumlah petambak garam, luas lahan yang digarap untuk tambakgaram dan produksi garam rakyat dikabupaten Lamongan terus meningkat. Petambakpetambak garam tersebut bergabung dalam kelompokkelompok penerima program PUGAR sebanyak 42 kelompok tambak garam dan 3 kelompok pengolah garam.Produksi garam pada tahun 2011 sebanyak 14.800 ton yang dihasilkan dari $180 \mathrm{Ha}$ dengan jumlah petambak 180 orang. Produksi garam pada tahun tahun 2012 naik menjadi 29.949 ton yang dihasilkan dari 348.1 ha dan petambak yang terlibat sebanyak 363 orang. Alokasi anggaran BLM yang dikucurkan sebesar Rp. 900.000.000,- (Dinas KP Lamongan, 2012). Pada tahun 2013 produksi garam di perkirankan mencapai 30.000 ton dari luas lahan 350 ha dan perkiraan petambak yang terlibat sebanak 390 orang.

Potensi tersebut masih bisa ditingkatkan dengan ditemukannya teknologi tepat guna (TTG) Garam Arifin Sedayu Lawas. Inovasi TTG Garam Arifin Sedayu Lawas bisa mencapai 600 ton/ha/musim dengan asumsi masa panen bisa mencapai 100 hari. Keberhasilan program peningkatan garam di Kabupaten Lamongan tidak terlepas dari dukungan pemerintah dan pendampingan PPTK/Penyuluh dan peran aktif masyarakat pelaku usaha. Keberhasilan program tersebut akan membawa dampak pada perekonomian masyarakat perdesaan. Pembangunan berbasis perdesaan merupakan alternatif untuk mengurangi dampak dari pembangunan yang cenderung bias urban. Oleh karenanya perubahan paradigma terhadap pembangunan nasional juga harus diikuti dengan perubahan orientasi terhadap pembangunan ekonomi dan wilayah perdesaan yang tidak dapat lepas dari kebutuhan teknologi (Chozin et al., 2010). Teknologi yang dimaksud lebih bersifat teknologi yang tepat guna (appropriate technology) yang sesuai dengan karakteristik sosial ekonomi, sumberdaya alam dan lingkungan, serta kebutuhan masyarakat perdesaan dalam upaya meningkatkan taraf hidup dan kesejahteraannya melalui pemberdayaan potensi yang dimilikinya.

Terkait peningkatan daya saing produk dipasar global, maka penyempurnaan teknologi proses produksi dan pengolahan harus dilakukan untuk meningkatkan mutu produksi. Teknologi tersebut diharapkan dapatmeningkatkan kapasitas, kualitas nilai tambah (value added) hasil dan diversifikasi yang berkontribusi terhadap ketahanan pangan nasional. Dalam proses produksi masih banyak dijumpai pemborosan sumberdaya, penyimpanan atau gudang yang kurang baik menyebabkan kehilangan produk garam bisa mencapai $10 \%$ dari total produksi.

Permasalahan dalam usaha tambak garam adalah sempitnya waktu dalam satu musim yang bisa dimanfaatakn untuk proses pembuatan garam. Salah satu upaya percepatan untuk menghasilkan air tua, dilakukan dengan menambahkan "doping" garam ke air muda. Dengan penambahan "doping" garam ini, maka dapat mempercepat penuaan air menjadi BE-25 yang merupakan kondisi ideal untuk proses pengkristalan garam. Penggunaan doping garam dapat memangkas siklus penuaan air sampai beberapa hari, sehingga dapat meningkatkan jumlah siklus produksi dalam satu musim. Penggunaan doping garam secara total dapat meningkatkan produksi dan meningkatkan keuntungan yang diterima oleh petambak garam.

\section{METODOLOGI}

\section{Waktu dan Lokasi Penelitian}

Penelitian dilakukan pada tahun 2013 di beberapa kawasan sentra produksi garam di Kabupaten Lamongan.

\section{Jenis dan Sumber Data}

Data primer diperoleh melalui wawancara dengan menggunan kuesioner yang sudah disiapkan. Data yang dikumpulkan adalah terkait keragaan teknologi usaha KP terkait dengan usaha peningkatan produksi garam.

Data dan informasi tentang keragaan teknologi dan proses difusinya dikawasan KIMbis Lamongan diperoleh dari penyuluh perikanan, pejabat Dinas Kelautan dan Perikanan, PPTK, HNSI, Nara sumber yang berkompeten, dan para pelaku usaha di wilayah Kabupaten Lamongan.

Data dan informasi yang dikumpulkan adalah informasi teknis kegiatan dari tipologi usaha petambak garammulai dari persiapan, pelaksanaan proses produksi. Kegiatan petambak garam meliputi: informasi produksi, kelompok usaha, pemasaran dan peningkatan kualitas dan nilai tambah, dan produk yang dihasilkan. Identifikasi meliputi: aspek ekonomi yang berkaitan dengan investasi, biaya operasional, dan harga mulai dari input produksi dan harga produk.

\section{Metode Analisis Data}

Data yang diperoleh selanjutnya dianalisis dcengan pendekatan deskriptif-kualitatif. Analisis tersebut terutama difokuskan pada keragaan teknologi yang dikaji adalah teknologi yang ada dan dipergunakan serta teknologi yang sedang dintroduksi oleh lembaga kelitbangan yang meliputi kelompok pelaku, yaitu: kegiatan pada usaha pergaraman (kelompok usaha KUGAR, luas lahan, inovasi yang tersedia dan potensinya). 
Kegiatan untuk mengumpulkan informasi terkait profil keragaan teknologi dilakukan oleh Tim KIMBis Pusat bersama dengan Tim KIMBis di lokasi. Diawali dengan diskusi-diskusi yang dilakukan dengan TIM Kimbis di Sekreatriat, maupun dengan para pelaku di beberapa lokasi dan nara sumber serta pihak-pihak yang berkompeten.

\section{HASIL DAN PEMBAHASAN}

\section{Teknologi Tepat Guna (TTG) Garam Arifin Sedayu Lawas}

Upaya peningkatan kualitas produksi garam dimaksudkan juga untuk meningkatkan pendapatan pelaku usaha garam. Salah satu usaha peningkatan produksi dan produktifitas serta kualitas telah dilakukan oleh pelaku usaha tambak garam di desa Sedayu Lawas, Kecamatan Brondong. TTG Garam Arifin Sedayu Lawas merupakan salah satu inovasi produksi garam dalam upaya meningkatkan produktifitas dan kualitas garam. TTG Garam Arifin Sedayu Lawas telah diuji coba pada musim garam tahun 2012. Hasil percobaan TTG Garam Arifin Sedayu Lawas dapat menghasilkan garam sebesar 108 ton/musim pada luas areal $2250 m^{2}$, yang berarti produktifitasnya sangat tinggi. TTG Garam Arifin Sedayu Lawas disempurnakan berdasarkan pengalaman dan pengetahuan dari praktek yang dilakukan, sehingga diharapkan teknologi tepat guna ini bisa benar-benar secara signifikan dapat meningkatkan produktifitas garam. Oleh karena itu perlu dukungan lembaga Litbang untuk menyempurnakan teknologi tepat guna TTG Garam Arifn Sedayu Lawas. TTG Garam Arifin Sedayu Lawas dapat menghasilkan produksi garam sebanyak 600 ton/ha/musim (dengan asumsi masa panen mencapai 100 hari).

Teknologi Tepat Guna (TTG) Garam Arifin Sedayu Lawas merupakan hasil dari pengembangan dan percobaan yang dilakukan secara mandiri dilahan yang berada disekitar rumahnya. Teknologi TTG ini menerapkan teknologi ulir dan filter untuk mempercepat penuaan air sekaligus menyaring kotoran yang masuk ke saluran. Proses percepatan penuaan air juga menggunakan metode "dopping" berupa penambahan garam kualitas rendah kedalam aliran air yang dialirkan ke ulir, penambahan doping akan mempercepat proses penuaan air sehingga dapat mempercepat proses produksi garam (Jamian, 2013). Proses percepatan penuaan air juga dilakukan dengan adanya akar-akar pohon bakau.

Penggunaan terpal dilakukan pada seluruh permukaan lahan, dengan perbandingan $6000 \mathrm{~m}^{2}$ untuk lahan meja Kristal dan $4000 \mathrm{~m}^{2}$ untuk proses penuaan air. Air tua dialirkan ke penampungan dan selanjutnya dialirkan ke meja-meja kristalisasi. Proses panen garam berlangsung 5-15 hari untuk setiap petak. Dengan luas meja kristalisisasi seluas $6000 \mathrm{~m}^{2}$ setiap hari dapat panen sekitar 2-6 ton, tergantung kondisi panas matahari. Apabila musim panen bisa berlangsung selama 100 hari, produksi dapat diperkirakan mencapai 400-600 ton/musim. TTG garam ini sudah mulai diadopsi oleh masyarakat lainnya yang berada disekitar lokasi, meskipun teknologinya belum bisa mengadopsi 100 persen, namun dengan mengadopsi sistem TTG produksi garam dapat ditingkatkan.

Selain TTG Garam Arifin Sedayu Lawas, di Kabupaten Lamongan juga terdapat kegiatan inovasi teknologi pemurnian garam yang bertujuan untuk meningkatkan nilai tambah garam berkualitas rendah menjadi garam konsumsi. Kegiatan ini dilakukan melalui kegiatan IPTEKMAS yang dilakukan oleh Pusat Penelitian dan Pengembangan Sumberdaya Laut dan Pesisir. Kegiatan IPTEKMAS garam didesa Banjarwati Kecamatan Paciran yang dimulai tahun 2011. Pada tahun 2013, kegiatan IPTEKMAS telah menghasilkan prototype pengembangan usaha garam dan produk garam konsumsinya sudah di jual ke masyarakat. Program IPTEKMAS garam dilakukan bekerjasama dengan Koperasi Pondok Pesantren Sunan Drajat. Produk utama adalah garam standard konsumsi yang sudah diedarkan keberapa lokasi.

Permasalahan dalam usaha tambak garam adalah sempitnya waktu dalam satu musim yang bisa dimanfaatakn untuk proses pembuatan garam. Salah satu upaya percepatan untuk menghasilkan air tua, dilakukan dengan menambahkan "doping" garam ke air muda. Dengan penambahan doping garam ini maka dapat mempercepat penuaan air menjadi BE 25 yang merupakan kondisi ideal untuk proses pengkristalan garam. Penggunaan doping garam dapat memangkas siklus penuaan air sampai beberapa hari, sehingga dapat meningkatkan jumlah siklus produksi dalam satu musim. Penggunaan doping garam secara total dapat meningkatkan produksi dan meningkatkan keuntungan yang diterima oleh petambak garam.

Pada tahun 2013 kelompok petambak garam di kecamatan Brondong yang berlokasi di empat desa, sepakat akan memperluas usaha tambak garam dengan menerapkan teknologi tepat guna (TTG) Garam Arifin Sedayu Lawas. Melalui kelompok yang telah ada beberapa telah mengusulkan untuk membuat usaha garam dengan luasan 1000-2000 meter/per pelaku usaha. Usaha garam ini bekerja sama dengan koperasi garam yang baru saja dibentuk. Pembiayaan usaha garam sistem terpal ini dilakukan melalui kredik bank yang disalurkan melalui koperasi. Petambak garam dapat melunasi pinjaman dari produksi garam yang menerapkan TTG Garam Arifin Sedayu Lawas pada masa produksi 2 minggu pertama, selebihnya petambah garam dapat menikmati keuntungan.

TTG Arifin Sedayu Lawas dapat meningkatkan produksi garam, dengan jumlah lahan pengristalan seluas $1000 \mathrm{~m}^{2}$, dapat dihasilkan garam $1200 \mathrm{~kg} /$ hari, dengan hasil tersebut pinjaman dapat dilunasi dengan produksi yang dihasilkan selama 15 hari, dengan asumsi harga garam pada waktu panen Rp. 400-500/ 
kg. Selanjutnya petambak garam dapat menikmati hasil garam sebagai sumber pendapatan. Diperkirakan terpal dapat dimanfaatkan selama dua musim, sehingga pada tahun ke dua petambak garam tidak perlu membeli terpal, namun hanya perlu membersihkan terpal dari lumpur.

\section{Prospek Pengembangan Teknologi Peningkatan Produksi dan Kualitas Garam}

Melalui program PUGAR usaha peningkatan produksi garam dilakukan, pelaku dan kelompok KUGAR di Kab Lamongan tersebara di beberapa desa di Kecamatan Brondong. Program Pugar telah dirasakan manfaatnya oleh masyarakat. Inovasi teknologi yang mulai dikembangkan untuk meningkatkan produksi adalah melalui penggunaan terpal. Inovasi produski dengan TTG Garam Arifin Sedayu Lawas.

Kelompok penerima Program PUGAR sebanyak 42 kelompok produksi garam dan 3 kelompok pengolahan (perebus) garam (Tabel 1).

Anggoata kelompok bergabung dalam kelompok dengan anggaota 7-10 orang per kelompok. Jumlah kelompok penerima program PUGAR sebanyak 42 kelompok tambak garam dan 3 kelompok pengolahan garam tradisional (Tabel 2).

Garam yang dihasilkan petambak garam secara tradisonal biasanya mutu KW 2 dan KW3, masih jarang petambak yang dapat menghasilkan kualitas produksi garam KWI. TTG garam Arifin Sedayu Lawas merupakan salah satu upaya untuk meningkatkan produksi sekaligus peningkatan kualitas garam. Produksi garam dengan TTG Garam menghasilkan produksi garam dengan kualitas KW1 dan KW2. Produk garam yang dihasilkan merupakan bentuk kristal putih yang sebagian besar merupakan produk KW1 dan KW2.
Tabel 2. Kelompok Pengolahan Garam Rakyat Kecamatan Brondong, Kabupaten Lamongan, 2013.

\begin{tabular}{cllc}
\hline No & \multicolumn{1}{c}{ Alamat } & \multicolumn{1}{c}{ KUGR } & $\begin{array}{c}\text { Jumlah } \\
\text { Anggota }\end{array}$ \\
\hline 1 & $\begin{array}{l}\text { Ds. Sendangharjo } \\
\text { Kec. Brondong }\end{array}$ & KARYA MANDIRI & 9 orang \\
2 & $\begin{array}{l}\text { Ds. Sedayulawas } \\
\text { Kec. Brondong }\end{array}$ & $\begin{array}{l}\text { CAHAYA } \\
\text { LESTARI }\end{array}$ & 8 orang \\
3 & $\begin{array}{l}\text { Ds. Tunggul } \\
\text { Kec. Paciran }\end{array}$ & SAREM & 8 orang \\
& MAKMUR & \\
\hline
\end{tabular}

Sumber : Dinas Kelautan dan Perikanan Kab. Lamongan (2012).

Kebutuhan untuk keperluan pasar lokal baik untuk penggaraman ikan dan proses produksi ikan olahan memerlukan garam dalam bentul kristal halus. Oleh karena itu produk garam harus diproses melalui penggilingan sehingga dihasilkan kristal halus yang memenuhi standar yang diinginkan oleh konsumen. Proses pengolahan garam menjadi garam halus memerlukan teknologi tersendiri. Mesin tersebut telah dimodifikasi, sehingga dapat memproses garam menjadi produk garam halus yang dipersyaratkan oleh pengguna.

Garam berkualitas konsumsi diperlukan peralatan mesin penghalus dengan menggunakan mesin penggiling. Mesin penggiling ini biasanya dimodifikasi dari mesin yang sadah ada. Di wilayah kecamatan Brondong masih sedikit alat mesin penggiling yang dapat menghasilkan garam sesuai dengan yang dibutuhkan pasar. Mesin pengering masih perlu dimodifikasi agar dapat menghasilkan kualitas garam halus. Diperlukan keahlian khusus untuk dapat menghasilkan mesin penggiling yang sesuai dengan kebutuhan pasar.

\section{Peranan Inovasi IPTEK melalui IPTEKMAS}

Peran lembaga penelitian dan pengembangan (litbang) sangat dibutuhkan untuk memodifikasi mesin

Tabel 1. Kelompok Usaha Garam (KUGAR) Kab. Lamongan yang Tergabung Dalam Program PUG Kelompok Tambak Garam.

\begin{tabular}{|c|c|c|c|c|c|}
\hline No & Alamat & Nama Kugar & Luas Lahan (Ha) & $\begin{array}{l}\text { Jumlah } \\
\text { Kelompok }\end{array}$ & $\begin{array}{l}\text { Jumlah } \\
\text { Anggota }\end{array}$ \\
\hline 1 & $\begin{array}{l}\text { Ds. Sidomukti } \\
\text { Kec. Brondong }\end{array}$ & $\begin{array}{l}\text { Sidomakmur I sd Sidomakmur } \\
\text { VI (6 Kel PUGAR) }\end{array}$ & 49,7 & 6 & 48 orang \\
\hline 2 & $\begin{array}{l}\text { Ds. Brengkok } \\
\text { Kec. Brondong }\end{array}$ & $\begin{array}{l}\text { Karya Makmur I s/d Karya } \\
\text { Makmur VI (6 Kel PUGAR) }\end{array}$ & 51,7 & 6 & 50 \\
\hline 3 & $\begin{array}{l}\text { Ds. Sedayulawas } \\
\text { Kec. Brondong }\end{array}$ & $\begin{array}{l}\text { Karya Lestari I s/d Karya } \\
\text { Lestari XI (10 Kel PUGAR) }\end{array}$ & 97,9 & 11 & 86 orang \\
\hline 4 & $\begin{array}{l}\text { Ds. Labuhan } \\
\text { Kec. Brondong }\end{array}$ & $\begin{array}{l}\text { Beruang I s/d Beruang VIII (8 } \\
\text { kel PUGAR) }\end{array}$ & 75 & 10 & 70 orang \\
\hline 5 & $\begin{array}{l}\text { Ds. Lohgung } \\
\text { Kec. Brondong }\end{array}$ & $\begin{array}{l}\text { Karya Agung I s/d Karya } \\
\text { Agung VIII (8 kel PUGAR) }\end{array}$ & 78 & 8 & 80 orang \\
\hline 6 & Kec. Brondong & Makmur Sejati & 6,8 & 1 & 8 orang \\
\hline 7 & Kec. Brondong & Karya Sejahtera & 7 & 1 & 7 orang \\
\hline 8 & Kec. Brondong & Sumber Makmur & 7,5 & 1 & 7 orang \\
\hline
\end{tabular}

Sumber: Data primer diolah (2013) 
khusus penggiling garam yang dapat menghasilkan garam halus dengan ukuran yang diminta pasar. Inovasi melalui kegiatan Iptekmas telah menghasilkan prototime mesin untuk meningkatkan kualitas garam menjadi kualitas garam konsumsi melalui proses pencucian. Alat dan mesin ini masih terus dalam penyempurnaan. Pengembangan alat pemurnian garam tersebut bekerja sama dengan Koperasi Pondok Pesantren Sunan Drajad di Kecamatan Paciran. Pada saat ini mesin tersebut telah mampu menghasilkan garam kualitas konsumsi sebanyak 1 ton per hari. Produksi garam konsumsi tersebut telah dipasarkan di beberapa lokasi pasar disekitar Lamongan dan Tuban. Arah pengembangan model peralatan tersebut bisa menjadi model yang diaplikasi dibeberapa sentra produksi garam.

Kabupaten Lamongan merupakan salah satu produsen ikan terbesar di Propinsi Jawa Timur, dengan jumlah produksi lebih kurang 109.458,38 ton/tahun pada tahun 2012 (tangkap dan budidaya). Produksi perikanan tangkap laut terpusat di PPN (Pelabuhan Perikanan Nasional ) Brondong dan empat PPI (Weru, Kranji, Lahgung dan Labuan). Dengan produksi ikan segar yang begitu banyak diperlukan garam dalam jumlah yang besar terutama untuk bahan baku pembuatan es, pembuatan ikan asin, proses pengolahan ikan oleh industri maupun oleh rumah tangga.

Kebutuhan garam untuk industri pengolahan ikan sebagian masih dipenuhi dari luar daerah dan sebagain dapat dipenuhi dari produk lokal. Adanya pasar yang terbuka merupakan salah satu peluang untuk meningkatkan produksi garam lokal yang dapat memenuhi kebutuhan pasar sesuai dengan kualitas yang diinginkan pasar. Gambaran produksi garam lokal dengan penerapan teknologi tepat guna (TTG) garam Arifin Sedayu Lawas. Apabila asumsi masa panen garam selama 100 hari terpenuhi maka potensi produksi 600 ton/ha/musim, dapat dipenuhi. Apabila penerapan teknologi tepat guna tidak penuh dan masa panen kurang dari 100 hari maka digunakan faktor produksi untuk mengetahui perkiraan produksi garam yang bisa dihasilkan.

Asumsi produksi garam kabupaten Lamongan dengan menggunakan TTG Garam Arifin Sedayu Lawas sebesar 204.000 ton/tahun, dengan asumsi luas produksi 340 ha dan produktifitas 600 ton/ha (apabila musim panen mencapai 100 hari). Berdasarkan pengalaman dua tahun terakhir produksi belum bisa mencapai 600 ton/ha, namun dengan musim panen selama 45 hari produksi garam TTG garam mencapai sekitar 175.000 ton/ha/musim. Berarti produksi garam baru mencapai sekitar $30 \%$ dari potensi produksi garam hasil TTG. Faktor utama belum tercapainya target produksi adalah, musim hujan yang baru berakhir pada bulan Juli, sehingga produksi awal baru bisa panen pada awal September 2013 dan musim hujan yang dating lebih awal, sehingga target hari produksi tidak terpenuhi. Dengan demikian, pengembangan tambak garam di Kabupaten Lamongan dapat dilakukan melalui penyempurnaan paket teknologi pemurnian garam. Kemudian dilanjutkan juga pendampingan serta penguatan jejaring antar penerima program Iptekmas (IPTEK untuk Masyarakat) Garam (Gambar 1).

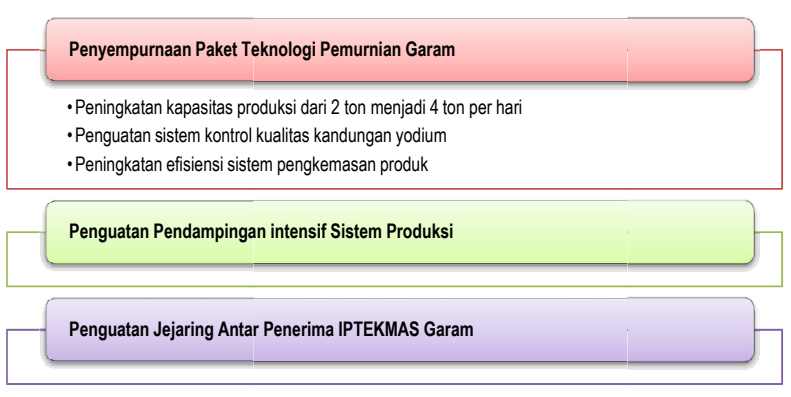

Gambar 1. Sistem Alur Pengembangan Garam Sumber : Balitbang KP, 2013

Tabel 3. Estimasi Kebutuhan dan Produksi Garam di Kabupaten Lamongan.

\begin{tabular}{|c|c|c|c|}
\hline No & Uraian & Satuan & Volume \\
\hline 1 & Kebutuhan garam untuk industri perikanan & ton per tahun & 90,000 \\
\hline 2 & $\begin{array}{l}\text { Produksi lokal (dengan teknik produksi tradisional) : } \\
340 \text { ha x } 80 \text { ton/ha/musim }\end{array}$ & ton & 27.200 \\
\hline 3 & Kekurangan $=90.000-27.200$ & ton per tahun & 62,800 \\
\hline 4 & $\begin{array}{l}\text { Prospek TTG (Asumsi Optimis, dengan masa panen } 100 \\
\text { hari) = potensi produksi } 600 \text { ton/ha/musim }\end{array}$ & Ton/ha/musim & 600 \\
\hline 5 & Potensi produksi 340 ha dgn TTG (340 ha x 600 ton/ha) & ton/thn & 204,000 \\
\hline 6 & Total Produksi berdasar faktor produksi $80 \%{ }^{1)}$ & ton/ha/musim & 163,200 \\
\hline 7 & Total Produksi berdasar faktor produksi $70 \%$ & ton/ha/musim & 142.800 \\
\hline 8 & Total Produksi berdasar faktor produksi $60 \%{ }^{1)}$ & ton/ha/musim & 122.400 \\
\hline 9 & Total Produksi berdasar faktor produksi $50 \%{ }^{1)}$ & ton/ha/musim & 102.000 \\
\hline
\end{tabular}

Keterangan: ${ }^{1)}$ Apabila TTG Garam belum bisa mencapai 100), yaitu dengan faktor produksi (prosentase yang dihasilkan dari produksi dengan target optimistis

Sumber : Analisis data primer, 2013 


\section{KESIMPULAN DAN REKOMENDASI KEBIJAKAN}

Kabupaten Lamongan mempunyai potensi lahan tambak garam seluas $350 \mathrm{Ha}$, teknologi yang sudah berkembang adalah teknologi sederhana yang sudah ada di masyarakatdan dilakukan secara turun termurun. Upaya pengembangan dan peningkatan produktifitas dan nilai tambah garam dilakukan melalui program IPTEKMAS dan PUGAR serta adanya inovasi yang dihasilkan oleh masyarakat setempat yaitu Teknologi Tepat Guna (TTG) Garam Arifin Sedayu Lawas. Sinergi antar pelaku dengan program-program yang sudah ada untuk peningkatanproduktifitas dan nilai tambah perlu selalu ditingkatkan. Melalui sinergi IPtekmas, PUGAR, dan KIMBisn, program pemberdayaan peningkatan produktifitas garam dapat berhasil.

Penerapan inovasi teknologi disertai dengan pendekatan kepada pelaku (petambak garam) merupakan langkah yang tepat agar teknologi yang diterapkan dapat diterima oleh masyarakat. Pendekatan seperti ini perlu diperhatikan oleh pemerintah, yang selama ini lebih berorientasi pada bantuan fisik tidak disertai dengan pendekatan kepada pelakunya (pendampingan dan peningkatan kapasitas SDMnya). Program yang berasal dari alokasi anggaran Dana Alokasi Khusus (DAK), Tugas Perbantuan (TP) selama ini lebih banyak mengalokasikan anggaran untuk bantuan berupa fisik, untuk kedepan perlu evaluasi agar bantuan anggaran untuk pendampingan dan peninkatan kapasitas SDM bias proporsional, sehinggan bantuan-bantuan fisik bisa diikuti dengan bantuan pendampingan sehingga kapasitas SDM masyarakat bias meningkat.
Keterkaitan dan sinergitas antar pelaku program (PUGAR, Iptekmas, KIMBis, Penyuluh, dan PPTK) sangat diperlukan, sehingga program tidak berjalan sendirisendiri sehingga mampu membangun modal sosial (hubungan saling percaya, norma yang efektif dimana kepentingan kelompok ditempatkan diatas kepentingan pribadi, dan munculnya jejaring (network) dan keterkaitan (linkage), dengan demikian program bisa berjalan efektif mencapai tujuannya.

\section{DAFTAR PUSTAKA}

BPS. 2012. Lamongan Dalam Angka. Badan Pusat Statisik Kabupaten Lamongan

Badan Litbang Kelautan dan Perikanan 2012. Kebijakan Pengembangan Garam. Badan Litbang Kelautan dan Perikanan.

Badan Litbang Kelautan dan Perikanan. 2013. Kebijakan Litbang Kelautan Dan Perikanan Mendukung Industrialisasi Garam Rakyat. Makalah Disampaikan pada Acara Peluncuran Program IPTEKMAS Garam, Surabaya, 24 Juni 2013

Chozin, M.A., Sumardjo., R. Poerwono., A. Purbayanto., A. Khosman., A. Fauzi., T. Toharmat., Hardjanto dan K.B. Suminar (Penyunting) 2010. Pembangunan Perdesaan dalam Rangka Peningkatan Kesejahteraan Masyarakat. IPB Press,. Bogor

Dinas Perikanan dan Kelautan Kabupaten Lamongan. 2012. Laporan Tahunan Dinas Kelautan dan Perikanan Kabupaten Lamongan. Dinas Kelautan dan Perikanan Kabupaten Lamongan

Jamian, A. 2013. Buku Panduan Teknologi Tambak Garam Terpal. Crayon Publishing. Lamongan 